\title{
POTENTIAL OF AGRICULTURAL PRODUCTION AND ITS IMPACT ON INSURANCE PREMIUMS
}

\author{
Jelena Birovljev ${ }^{1}$, Željko Vojinović ${ }^{2}$ Mladenka Balaban ${ }^{3}$
}

\begin{abstract}
Summary
Food production is becoming very important and it receives priority in relation to other activities in the world. As the number of inhabitants of the planet grows, food production has greater significance. Its production will certainly be affected by climate changes and the potential of agricultural land, which will be followed by changes in insurance cover of crops.

Total area of arable land doesn't have the same quality, but it's especially common for underdeveloped and developing countries is that arable land is not used in the appropriate percent.

For Serbia which belongs to that group of countries with low yield on arable land, it can be pointed out that insurance does not cover a sufficient share of that area. The reason for this lies in the lack of trust of potential insured, habits and consciousness of the insured, economic policy pursued by the state in relation to this issue, inadequate training of insurance agents and the lack of proper insurance products.
\end{abstract}

Keywords: agriculture, arable, insurance, premium, damage, growth and development.

JEL: G22, Q14

\section{Introduction}

In Serbia, agriculture is of great importance, from which the importance of insurance of agricultural production stems. Agronomy usually happens on open and unprotected space, which means that it is exposed to various risks. These dangers occur almost every year, with greater or lesser force, causing great damage, and often on catastrophic proportions. Therefore the security of this production, which plays a significant role in the economic protection and promotion of agriculture, is one of the riskiest types of insurances (Swiss Re, 2011a).

1 Jelena Birovljev, Professor, Ph.D., Economic faculty Subotica, Univerzity Novi Sad, Segedinski put Street no. 9-11, Subotica, Serbia, Phone: +381 638395971 E-mail: birovljevj@ef.uns.ac.rs

2 Željko Vojinović, Associate professor, Ph.D., Economic faculty, Independent university Banja Luka, Veljka Mladenovića Street no. 263-12 E, B\&H, Phone: +381 648832600 E-mail: zv@,inbajmok.com

3 Mladenka Balaban, Associate professor, Ph.D., Institute of Economic Science, Zmaj Jovina Street no. 12, Belgrade, Serbia, Phone: +381 6931059 72, E-mail: mladenka.balaban@ien.bg.ac.rs

EP 2015 (62) 3 (705-722) 
The proportion of the danger is further affected by a proportionally long production cycle, typical for this type of production. When, to numerous natural disasters, to which agricultural production is exposed to, added to other risks to crops and the influence of the state, which is not always go hand to hand to farmers, it is clear that crop production is exposed to a significant extent of financial risk (Carter, Smith, 2007; Morgan et al., 2012).

There are numerous hazards that affect agricultural production. These dangers mostly come from nature and may affect large areas and cause great damage. Man is sometimes the cause of these events (Wright, Hewitt, 1994; Costello, 2012).

Underdevelopment of insurance of agricultural production, thinking of crops, is visible in the data which we represented in the paper. Those are the results of insurance companies which are important for the assessment of situation in that area, and which are derived from small usage of agricultural land and very small number of contracted coverages of crops. These data were compared with data from other countries with adequate parameters.

This paper shows the potential of agricultural land, arable agricultural land, supporting results on insurance through premiums, technical result and damage. The sum of insured which is given in this paper can certainly be much higher with an increase in arable area and higher insured arable land. Hence the result monitored through premiums, technical results and damage will be higher. The mechanism of insurance is based on the atomization of risk, high diversification and statistics of large numbers (Carter, Smith, 2007).

The starting point for preparation of this work was the data on insurance of agricultural production in Serbia. In our Insurance Law, it is classified as other property insurance, along with insurance of machinery breakdown, construction insurance, household insurance, insurance of animals etc. (Brkanić, 1996).

The National Bank of Serbia only provides information on total premiums and claims by types of insurance (National Bank of Serbia, 2014). Source of information on total area of Serbia, total agricultural, used and arable land is the yearly statistical overview for the Republic of Serbia. Data on the total number of households, areal intendedness and concentration of the used and arable land come from the same source. For comparative analysis with other countries, data on average size of lots, average value of crops is given.

The authors have collected data from societies that deal with this type of insurance and which are recorded to provide risk coverage to agricultural production on insured areas, sum of insurance on agricultural productions, damaged insured areas and technical results.

Data on total, agricultural and arable land in Serbia, the number of farmers and basic climate data were taken from the yearly statistical overview for the Republic of Serbia. With the data for Serbia, while doing international comparison, competent data for other countries was used.

All of the data was analyzed in the direction of confirming the theses of this work, with the application of quantitative and qualitative methods. The potential of agricultural production provides the basis for the development of insurance businesses through an increase of the 
insured area. The insured area was taken as an independent variable from which, with various analysis methods, which are applied in this paper, can be concluded how much the results of the insurance activity could be higher. Testing the hypothesis we came to a conclusion on the justification for setting the same. With correlation and regression analysis, we came to the conclusions that we present in this paper.

All of the observed data was collected over an eight year period, from 2006 to 2013, so we believe that with the use of different methods of analysis on the observed sample a result was produced which may make the insurance companies, farmers and the state decide on undertaking concrete measures.

\section{Characteristics of agricultural production in Serbia}

The Republic of Serbia covers a total area of 8,840,000 ha. Agricultural land covers $5,346,597$ ha, that is, $60 \%$, of which 3,437,423 ha is utilized agricultural area, and $2,513,154$ ha arable land. The difference between used and arable land is mainly meadows and pastures. From the standpoint of security, arable land are significant, while meadows and pastures as a rule do not.

For insurance the essential information is the number of farms, i.e. the average size of used land per farm because this can influence the level of costs of underwriting and negotiation of insurance protection (Roberts, 2005). So in Serbia we have surveyed the following number of farms:

- Agricultural holdings $(631,622)$,

- Family farms $(628,555)$,

- $\quad$ Legal entities $(2,567)$.

Seeing as how the insured area is taken as an independent variable in the work, and it occurs as a result of sale of insurance coverage of agricultural production from a number of risks, an important factor of influence on the result is the concentration or dispersion of land which is cultivated. This factor is dominant in Serbia, especially if you take that the majority of arable land, over 55\% is in Vojvodina, a total of 1,589,065 ha, out of which 315,247 ha in Južni Banat.

The total result on arable land in the last years of the observed period is at around 3.2 billion euros. The average value as a result of agricultural activities per farm is at about 900 euros. This is certainly the result of the average size of farms in Serbia which is at 5.3 ha, in the Czech Republic 152.4 ha, while Malta it is just about 9 ha. For insurance companies average arable land per capita is essential, which may result in a significant impact on the cost of implementation of insurance protection, which in Serbia is at 0.5 ha, and in Banat even at 1.23 ha per capita.

Results of insurance companies show that the premium collected is at around ten million euros, and in further work data is presented yearly, and if all arable land was insured this premium could amount to 130 million euros. From a total of 28 insurers, the 
number working on the territory of Serbia, eleven of them deal exclusively with nonlife insurance, while six deal with life and non-life insurance classes. In the collected insurance premium agricultural production, two houses are with by far the largest share, DUNAV and DDOR, while from the other fifteen only a few offer insurance coverage of agricultural production.

The risks that threaten agriculture are divided into basic and additional. Hail, fire and lightning represent basic risks, storms, spring frost, autumn frost and flood fall in additional risks. Under the influence of climate changes, one insurance company as an additional risk recently introduced drought. All risks in one product, i.e. Comprehensive crop insurance (Swiss Re, 2011) does not exist in Serbia, and we estimate that new crop insurance products won't be introduced. The concept of management of agro risks (Chambers, Quiggin, 2004), whose part is insurance, is rarely present in Serbia. Its implementation is gradually influenced by the emergence of big landowners, which occurred after the commencement of the privatization process fifteen years ago.

Insurance of agriculture is voluntary in Serbia. General conditions of crop insurance, except husbandry, predict contracting franchises in the range from $5 \%$ to $50 \%$. Farmers pay a lower premium through the introduction of franchisees but when damage occurs they are not satisfied with it, because they expect to be paid the total amount of damage they have suffered. Since the damage to fruit compared to secured areas are by far the largest, insurance companies insist on franchising these crops, usually $10-20 \%$.

It is almost impossible to specify everything that might influence production, but we will still mention some of the important factors: (Brkanić, 1996,) the deficit or surplus of moisture in the soil and in the air (droughts or excessive rain), too high or low temperature of air and soil (frost or heat stroke), lack or excess of plant nutrients, hail, stormy winds, flood, fire, plant diseases (fungi, bacteria, viruses), pests (insects, rodents), weed (Maliva, Missimer, 2012).

In 2007 the state introduced subsidizing insurance premiums, but only for registered farms where agriculture is the only source of income. During the first two years subsidies amounted to $30 \%$ of the premium, to be increased to $40 \%$ from 2009 onwards. Approximately same volume of subsidies exists in other European countries with which we performed the comparisons with, while this kind of state aid is not introduced in half of them (Tsakiris, Vangelis, 2005).

In order to avoid a big burden on the budget, and in accordance with the Law on local governments, there is a possibility for municipalities to further stimulate farmers to purchase insurance protection. The practice in other countries is that additional subsidies can be approved by municipalities, according to their ability. It is estimated that there are around 450,000 registered farms, but a very small percentage is insured from the risks that endanger agricultural production. Even though the IT-sector in our country is not at a low level there is still no list of insured farms. 


\section{The result of agricultural production in Serbia}

In Table 1 there is the data on insured areas and their share in the total utilized and arable land. From the table we see that the 2008 is the year with the largest insured area, all up to 2013. After a sharp decline in 2009, in the next year there was an improvement, but in the last year analyzed the insured area covered approximately $10 \%$ of the total cultivated land.

Table 1. The share of total insured area in total used and cultivated in Serbia 20062013.

\begin{tabular}{|c|c|c|c|}
\hline Year & Area (ha) & $\begin{array}{c}\text { Share in total utilized } \\
\text { agricultural areas, } \%\end{array}$ & $\begin{array}{c}\text { Share in arable land, } \\
\mathbf{\%}\end{array}$ \\
\hline 2006 & 260,828 & 7.58 & 10.38 \\
\hline 2007 & 292,420 & 8.50 & 11.64 \\
\hline 2008 & 302,957 & 8.81 & 12.05 \\
\hline 2009 & 231,482 & 6.73 & 9.21 \\
\hline 2010 & 254,846 & 7.41 & 10.14 \\
\hline 2011 & 252,980 & 7.36 & 10.07 \\
\hline 2012 & 297,948 & 8.67 & 11.86 \\
\hline 2013 & 354,425 & 10.31 & 14.10 \\
\hline
\end{tabular}

Source: authors'own calculation; Statistical Office of the Republic of Serbia (2012): Statistical Yearbook of the Republic of Serbia, Belgrade; Republički geodetski zavod, www.rgz.gov.rs (visited 18.01.2015). Agricultural census, 2012.

This movement of insured areas is maybe the consequence of world economic crisis which influenced the insurance industry in our country in 2008. From Table 1 it can be concluded how small the interest of farmers is for the insurance of their crops. Insurance coverage of $10-15 \%$ of the potential shows the weak state, but also the possibility which is at the disposal of insurance companies. On one side we have the insured area which is not getting bigger, the result is that the same number of farmers and on the other is the offer of ever increasing number of insurance companies. Those are the conditions for creation of disloyal competition, discounts which are not in accordance with tariffs, which may cause problems with payment of damages. By achieving better results, gathering greater premiums as a result of increasing insured areas, an atmosphere of trust and security would appear. 
Figure 1. Trend of insured area

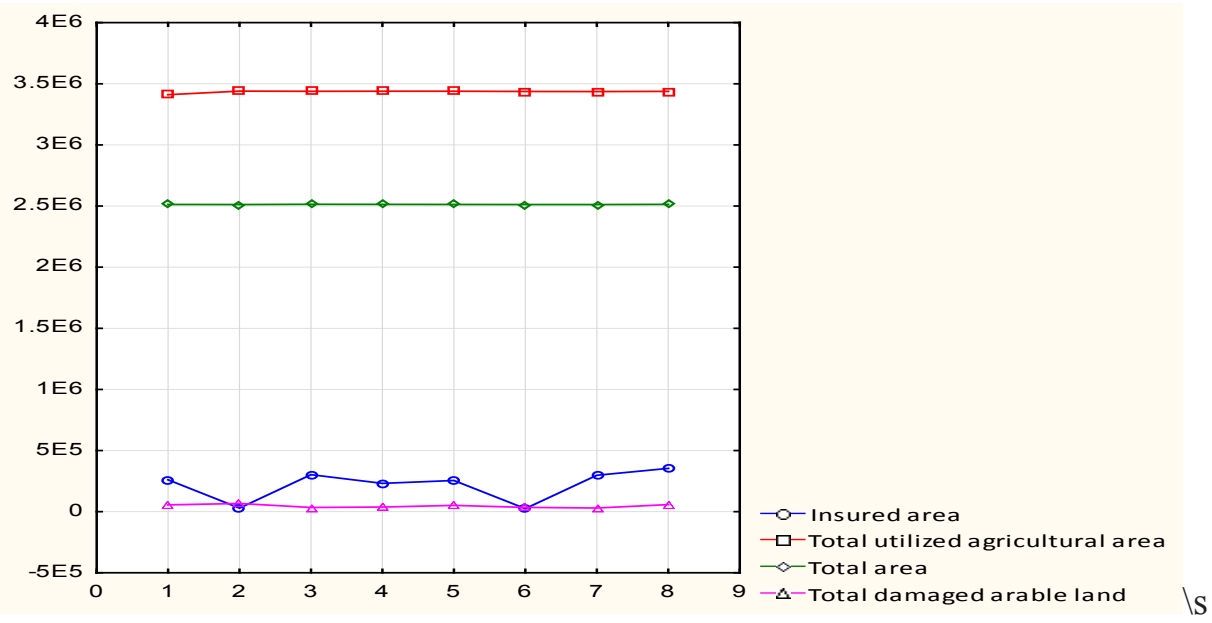

Source: authors'own calculation

The offer insurance services, working with clients continuously throughout an entire year, educating farmers, provision of subsidies and other stimulus measures would give results and open up opportunities to make use of the existing potential. A large increase in premiums would occur if there was an increase in the percentage of insurance of arable areas, without initiating an increase in arable land in the total agricultural area. That means the change of soil tillage which is not the subject of work.

\section{Business results of insurance companies}

Height of realized premiums is the first indicator of work success of insurance companies. The premium depends on the amount of insurance, which is usually the real crop value, it is specified by the insured and according to her value premiums are calculated. The sum insurance represents the maximum obligation of the insurer in case of damage and expressed per unit area.

The insurance sum, the name characteristical for this type of insurance depends on: the value of the insured crop,

- the expected yield per crop,

- $\quad$ Prices of crop products,

- $\quad$ structures of insured crops,

- $\quad$ size of the area which is occupied by crops.

Table 2 presents the average values of crops, sums insured and premiums earned during the period. It can be seen that the value of crops had a growth tendency depending on the secured area, which can be seen from the table above, with certain fluctuations. The growth in average value of crops is influenced by the growth of retail prices of agricultural products and other less important factors. 
The sum insured and premium growth depending on the average value of crops and fruits for the observed period with the same oscillations. The impact of prices of agricultural products is particularly significant in 2008 and 2011. The insured area was increased in 2008 by $4 \%$ compared to 2007 , and the sum insured almost $74 \%$. A similar situation occurred in in 2001 when the insured area decreased by $1 \%$ and the insurance sum increased by 33\%. Such disproportionality in relation to the insured areas and insurance sums is the result of growth of price of agricultural products. In order not to neglect that influence, and to give greater significance to the influence of size of the insured surface this was taken as an independent variable in the data collection.

Table 2. Average value of crops and fruits, the total amount of insurance, insurance premiums by years of agricultural production in Serbia 2006-2013 (€/ ha)

\begin{tabular}{|c|c|c|c|}
\hline Year & $\begin{array}{c}\text { Average value of crops } \\
\text { and fruits ( } \boldsymbol{~ / ~ h a ) ~}\end{array}$ & Sum & Premium \\
\hline 2006 & 55,934 & 14,589 & 611 \\
\hline 2007 & 60,624 & 17,728 & 751 \\
\hline 2008 & 104,092 & 31,536 & 1,105 \\
\hline 2009 & 88,937 & 20,587 & 746 \\
\hline 2010 & 92,700 & 23,624 & 794 \\
\hline 2011 & 122,590 & 31,012 & 969 \\
\hline 2012 & 135,800 & 40,461 & 1,126 \\
\hline 2013 & 149,889 & 53,124 & 1,503 \\
\hline
\end{tabular}

Source: National Bank of Serbia, Number of insurances, policyholders and premiums by type of insurance tariff in Serbia

Starting from data on the total insured areas and insurance sums, i.e. the value of the insured crop production, we have come to value of the insured crop per hectare, which is shown in the table.

Insurance is a mechanism in which the collected and billed premium serves for the payment of damages that the farmer suffered. That is the obligation of the insurer arising in contractual relations with the client. The premium is the price in the direct dependence on the insurance amount that is paid by the insured, and which should be sufficient to cover the risk in a certain period of time and on a large enough number of insured to diversify risk.

Higher premiums as the result of the insurance business in 2008 is a consequence of introducing new tariffs for the insurance of agricultural production and the measures taken by the then government prescribed. In the coming years premiums were stagnating due to the world economic crisis, movement of retail prices for grain and other factors.

After the great fall of 2010, there was a growth tendency of premiums, to be largest be the last year of the period. A better result was driven by slightly higher demand EP 2015 (62) 3 (705-722) 
for insurance protection, greater demand for agricultural products in the domestic market and increased exports to Russia. The rise in prices of agricultural products and fluctuations in the exchange rate of dinar certainly contributed to this result.

If we look at the share of premiums from insurance of agricultural production in total premium of non-life insurance, it does not exceed $2 \%$. Given the importance of agriculture in Serbia, then it is a very small share.

\section{Damage to crops and fruits}

Damage is another indicator of the results of the insurance activity. The damage is a consequence of the events of different risks in agriculture. Even though it's of local character, the risk of hail is the biggest cause of damage. An example of significant damage is a storm, which swept the entire municipality of Arilje in central Serbia in 2011, right before the maturation and harvesting of raspberries crops. The larger part of the total production of raspberries in Serbia is grown in this area. In the following tabular view processed data on the height of damage the damaged surface and the average size of damage per year was given. From the foregoing, it is evident that this indicator has a growth tendency in the eight-year period, with certain oscillations. Minimum damage occurred in 2012, while in 2010 and 2013 with the largest amount of damage.

In the observed period, the damage from 2007 is not negligible, especially if one takes into account that in that year the highest indicator of the damaged area is under crops. In 2013, the amount of the damaged area is also large even slightly higher than the figure for 2006.

Average damage per hectare is the highest in 2013 and 2010, which is appropriate given the extent of damage and its coverage of the protected areas.

Table 3. Overview of insurance claim of agricultural production in Serbia 2006-2013.

\begin{tabular}{|c|c|c|c|}
\hline Year & $\begin{array}{c}\text { Damages } \\
\text { million RSD }\end{array}$ & $\begin{array}{c}\text { Surface damage } \\
\text { ha }\end{array}$ & $\begin{array}{c}\text { Average damage } \\
\text { RSD / ha }\end{array}$ \\
\hline 2006 & 545 & 56,024 & 2,088 \\
\hline 2007 & 710 & 66,968 & 2,428 \\
\hline 2008 & 591 & 34,053 & 1,949 \\
\hline 2009 & 536 & 37,865 & 2,316 \\
\hline 2010 & 918 & 51,764 & 3,601 \\
\hline 2011 & 687 & 35,083 & 2,716 \\
\hline 2012 & 416 & 29,829 & 1,397 \\
\hline 2013 & 1506 & 57,824 & 4,250 \\
\hline
\end{tabular}

Source: National Bank of Serbia, Number and amount of claims by types of insurance and tariff 1) for Serbia; http://www.nbs.rs/export/sites/default/internet/english/60/60_2/izvestaji/ god_T2_2012.pdf. 
There was a large discrepancy in the movement of damage amount and the damaged surface, i.e. space of damage. The reason for this, which is especially visible in 2008 and 2012, should be sought in the structure of the damaged areas. The value of husbandries is much lower in relation to fruit crops. When damage occurs to husbandry crops damage amount is less for greater surface area while fruit has a different situation. Damage height to some extent depends on the business policy of the insurer, the choice of the insured if he is selective, choice of the objects of insurance and the application of price of crops, out of which the height of the sum insured depends on.

To what extent will the height of incurred losses, the size of land surface affected by the damage, the amount of the average damage per hectare depend on the coverage of crop insurance that is, on the coverage of different types of insured crops is shown by the correlation analysis.

The following chart illustrates the best for the observed 7 year period, movement of the insured sum, the total premiums and claims per year. We see that in the period 2006-2008, on charts 1 through 3, that the amount of insurance has grown from year to year, accompanied by premiums. During this period, the damage is increased in the first year and 2008 it was at a minimum.

Figure 2. Trend of insurance claims in agricultural production

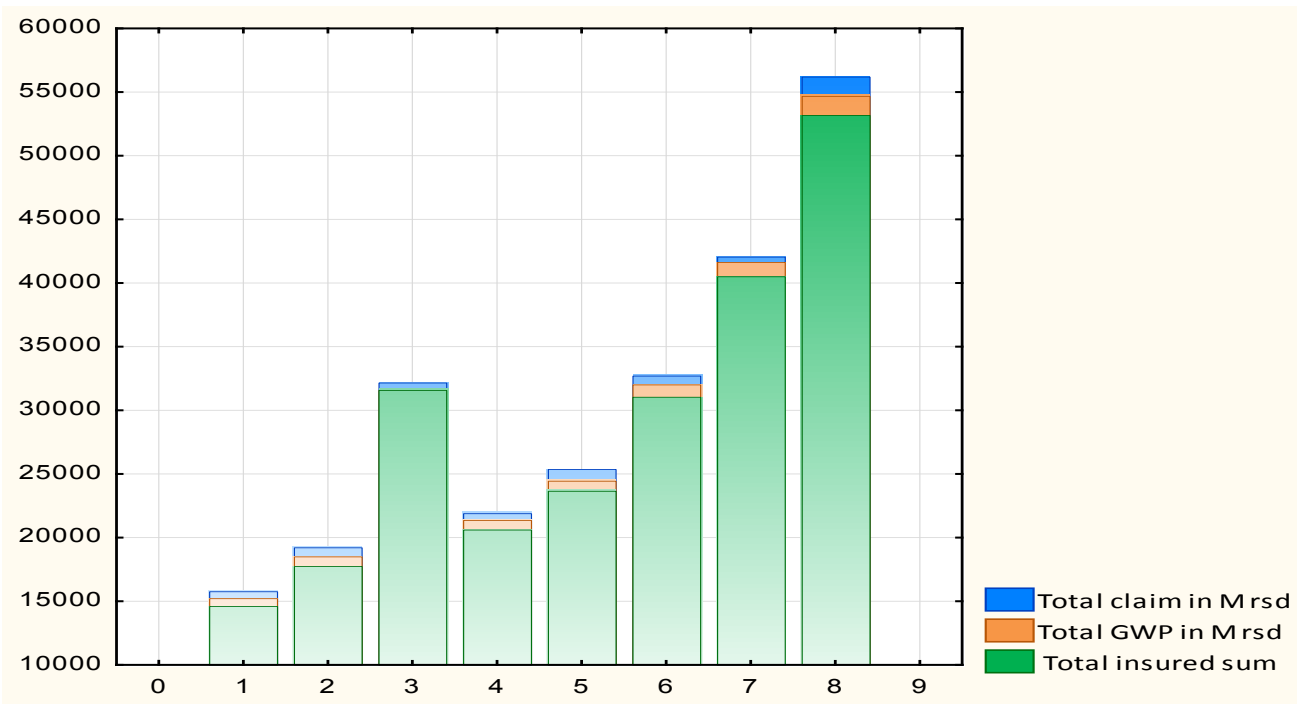

Source: authors'own calculation

\section{The technical result}

As the most important indicator of the insurance business with the application of fair presentation of premiums and claims is the technical result. It's common for the insured person not to be familiar with the technical result, which is achieved by implementing insurance protection. Fortified technical result is the quotient of damage and premiums and 
it shows the insured and the insurer what interest they could achieve. A positive technical results indicates unfavorable insurance that a client has, and the insurer is not ready to give up a part of the premium in this case. On the other hand, a negative technical result is not good for insurers because it involves him operating with a loss which in turn may have implications for policyholders.

The technical result is monitored in the short and long term, according to individual tasks, clients and by types of insurance. To select the optimal solution for farmers it is important to know what the result will contribute and its different approach to insurance protection.

In the observed period the technical result in the insurance of agriculture ranged from positive to negative to be negative only in two out of the eight year period. Damage indicators suggest that the negative technical result occurred in 2010 and 2013.

Table 4. The technical result in the insurance of agricultural production in Serbia 2008-2013

\begin{tabular}{|c|c|c|c|c|c|c|c|c|}
\hline Year & 2006 & 2007 & 2008 & 2009 & 2010 & 2011 & 2012 & 2013 \\
\hline $\begin{array}{c}\text { Claim/ } \\
\text { premium } \%\end{array}$ & 89 & 95 & 53 & 72 & 156 & 71 & 37 & 102 \\
\hline
\end{tabular}

Source: authors'own calculation

This result reflects the adequacy of premium rates in ensuring agricultural production. To a large extent it depends on the basic variables, insured area of arable land, but also other factors less important and which we mentioned in the framework of processing data on premiums and claims.

\section{Analysis of insurance results}

Terms for insurance of fruits and crops as well as the results of the insurance activity in the area, are similar to the data obtained from other countries: Bulgaria, Czech Republic, Slovakia, Hungary, Romania and Slovenia. Similar products and tariffs are applied and the fact is that in all of those countries there is no comprehensive crop insurance. Basic coverage of risks is against hail, fire and lightning and additional storms, frost and flooding. Recently cover against risk of drought was introduced.

In the structure of insurers in other countries we specified, agricultural insurance is offered by private companies, while in Serbia the leading insurer in this area is owned by the state.

According to the data collected we come to the conclusion that arable land covered by insurance protection in Serbia is far less than in other countries. Hungary and the Czech Republic have much higher share of insured areas in relation to arable, six times higher than the indicator in Serbia, while in Bulgaria it is seven times and in Ukraine ten times higher. This attests to the fact of good choice of independent variables in the work.

From the standpoint of international comparisons in insurance premiums amount of crop production, we emphasize that it is lower only in Bulgaria. In the Czech Republic and Hungary 
it is up to four to five times higher than in our country. Likewise, we emphasize that Serbia is the only one among the surveyed countries in which the technical result in crop insurance is averagely unfavorable because in the reported period it amounted to about $85 \%$. To be favourable it should not exceed $80 \%$. This results in that the Serbian insurers must realize gains in other branches of insurance - specifically, from the standpoint of agriculture, the beneficial effect of insurance of motor vehicles, buildings, equipment, and people employed in this industry spill and cover an unfavorable technical result in crop insurance (Marković, Jovanović, 2008).

In order to bring the correct conclusions what is the significance and potential of agricultural production for the insurance business, we will show the correlation relationship of the insured surface with the results of the insurance activities such as: the average sum insured, the total amount of insurance, total premiums, total damage of insured damaged surfaces, the average amount of damage and the technical result.

From the following table of the correlation analysis of the taken parameters, we see that there is a remarkable statistical significance in their correlation. However, in order to realistically show the movement and the impact of the insured surface and thus the total agricultural and farmland to the results in the insurance, we will take the regression analysis of the following variables which will also be dependent on:

- The total amount of insurance,

- Total premiums,

- The total damage,

- The technical result.

What is important to note is that we took a secured area as an independent variable, with the note that its movement certainly depends on the total area and area of arable land. As those two sizes move, so will the insured surface with the influence of other factors, general insurance factors such as acquisitions, products, social standards, state policy, agricultural development and investment in machinery and equipment. 
Table 5. Paired Samples Test

\begin{tabular}{|c|c|c|c|c|c|c|c|c|}
\hline \multirow[t]{2}{*}{ Insured area } & \multicolumn{5}{|c|}{ Paired Differences } & \multirow{2}{*}{$\begin{array}{c}\mathrm{t} \\
\text { test }\end{array}$} & \multirow{2}{*}{$\begin{array}{l}\text { Degrees } \\
\text { of } \\
\text { freedom }\end{array}$} & \multirow{2}{*}{$\begin{array}{c}\text { Stat. } \\
\text { relevant }\end{array}$} \\
\hline & $\begin{array}{l}\text { Aritmet. } \\
\text { mildfield }\end{array}$ & $\begin{array}{l}\text { Standard } \\
\text { Deviation }\end{array}$ & \begin{tabular}{|c} 
Standar \\
mistake \\
aritm \\
midlfield
\end{tabular} & $\begin{array}{r}95 \% \text { confic } \\
\text { Lower limit }\end{array}$ & $\begin{array}{l}\text { lent interval } \\
\text { Upper limit }\end{array}$ & & & \\
\hline \begin{tabular}{|c|l|} 
& Total \\
Pair & insured \\
1 & sum in m \\
& rsd
\end{tabular} & 251.90 & 30.25883 & 10.69811 & 226.60611 & 277.20014 & 23.546 & 7 & .000 \\
\hline \begin{tabular}{|c|l|} 
Pair & Total \\
insured \\
2 & $\begin{array}{l}\text { sum in } \mathrm{m} \\
\text { Isd }\end{array}$ \\
\end{tabular} & -669.63 & 256.8630 & 90.81480 & -884.38212 & -454.89638 & \begin{tabular}{|l|}
-7.374 \\
\end{tabular} & 7 & .000 \\
\hline \begin{tabular}{|c|l|} 
Pair & Total \\
claim in $\mathrm{m}$ \\
rsd
\end{tabular} & -457.63 & 321.5065 & 113.66972 & -726.42544 & -188.85306 & -4.026 & 7 & .005 \\
\hline \begin{tabular}{|c|l|l|} 
Pair & Technic. \\
4 & result
\end{tabular} & 196.61 & 55.88985 & 19.76004 & 149.88567 & 243.33583 & \begin{tabular}{|l|}
9.950 \\
\end{tabular} & 7 & .000 \\
\hline
\end{tabular}

Source:http://www.nbs.rs/export/sites/default/internet/english/60/60_2/izvestaji/god_T1T2_2012.pdf

The first result we got with regression analysis indicates that the insurance sum grows in-line with the increase in insured agricultural areas.

Figure 3. The total amount of insurance depending on arable land

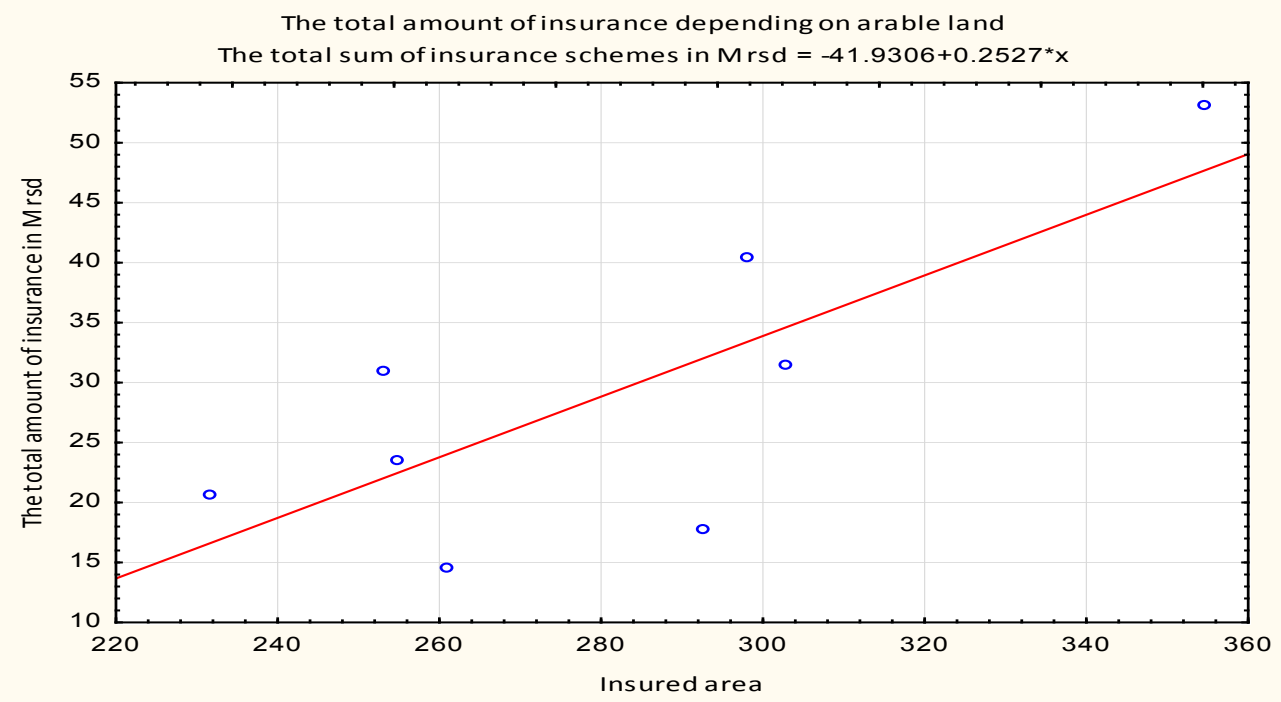

Source: authors'own calculation

In addition to the total amount of insurance we took the total insurance premium in the regression analysis as well. Trend of movement of total insurance premium is quite similar to the movement of the sum insured, and they are directly dependent. With the increase of insured surface, so will increase the insurance premium. 
Figure 4. The total GWP of insurance depending on arable land

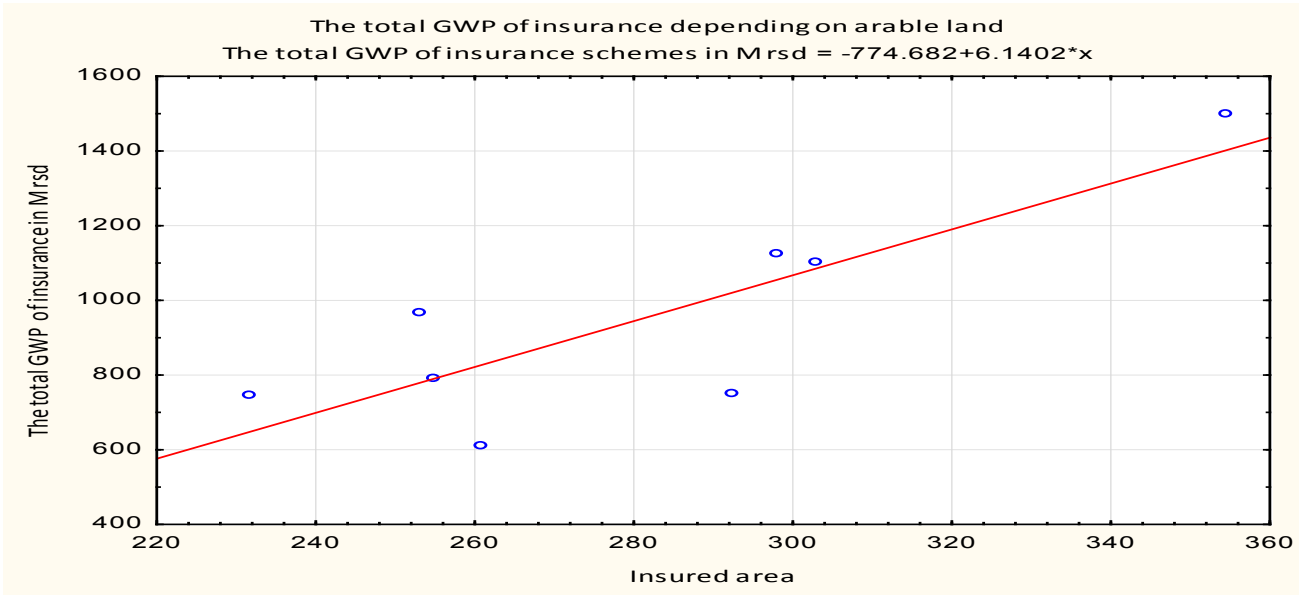

Source: authors'own calculation

Unlike the insurance sum on the insured agricultural land and the total insurance premiums in the same area, the movement of damage can be quite different and this is confirmed by the following chart.

Figure 5. The total claim of insurance depending on arable land

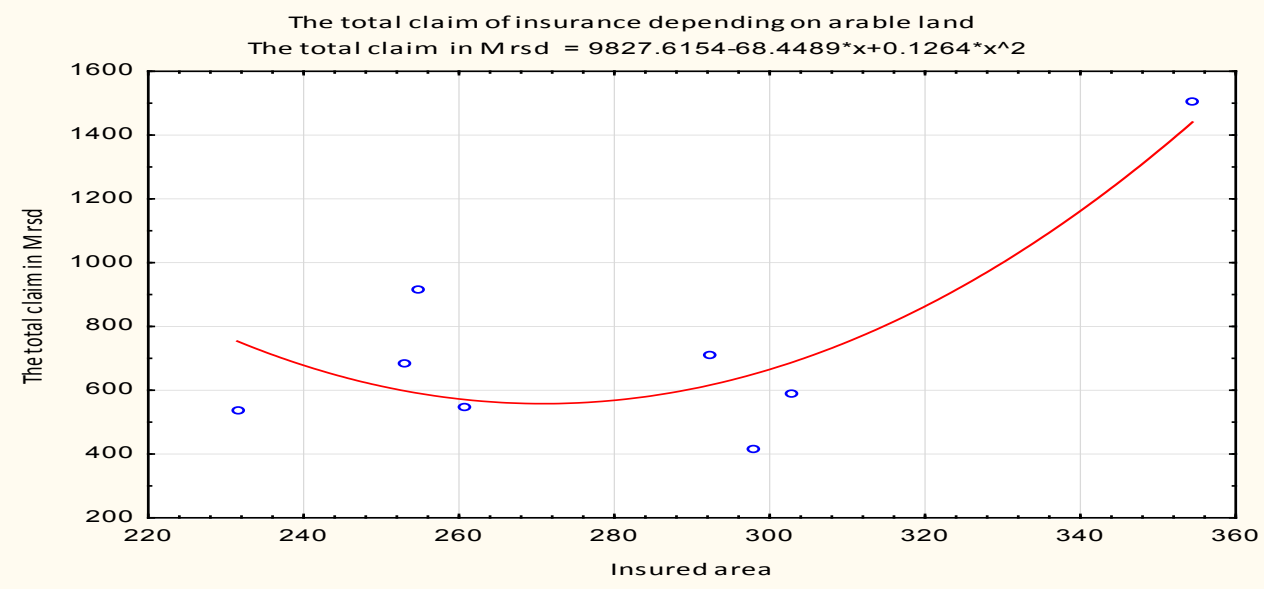

Source: authors'own calculation

We see that trend of losses in the reporting period 2006-2013 did not linearly vary with respect to the secured area. Future developments of damage should be planned in this way, especially taking into account the unstable weather conditions and major problems of flood risk and other disasters, which we expect to forecasts.

This does not mean that we should reduce the insurance coverage of agricultural production, from the perspective of risk for the insurers, on the contrary, increase efforts to diversify and atomize risks that threaten the domestic agricultural production. 
In this regard, we observe the movement of technical result of insurance companies in the period from 2006 to 2013, on insurance of agricultural production in Serbia. Although this result is variable and even negative in some years, however, still observing the whole period the result is positive. It's encouraging that agriculture has the potential with which this result could be even better, and that insurance companies have room to reduce costs and thus relieve the insured, and provide a realistic income to them.

Figure 6. Technical result of insurance depending on arable land

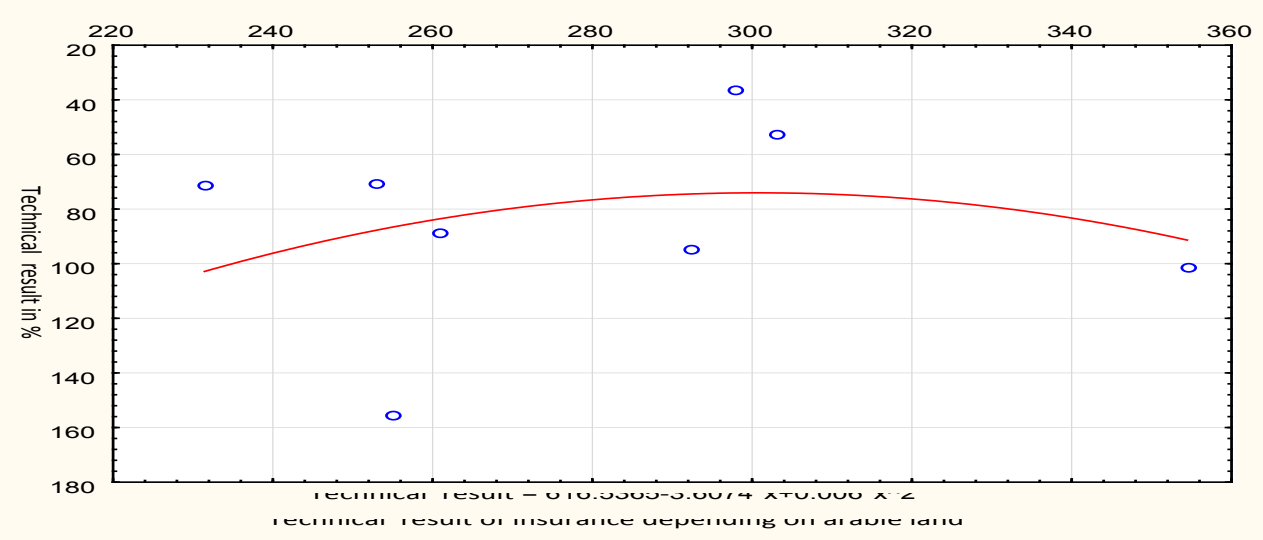

Source: authors'own calculation

All of the graphs are given with the formula of interdependence depending on variables with respect to the independent variable. In this work that is the insured area and the dependent are the amount of insurance, insurance premiums, claims and insurance technical result.

\section{Conclusion}

All data presented in this paper points to under-utilization of natural resources of agricultural land. A very small percentage of available land is cultivated. According the weaker results of agricultural activity occur.

Insurance as a supporting activity is at a very low level of development. The premium that is achieved could be increased up to ten times with greater utilization of agricultural land, along with more appropriate forms of insurance protection and greater influence of the state.

Insurance as a risk coverage is only used by big and professional farmers who are not so numerous. Unfortunately, a large percentage of small-scale farmers with small property simply avoids insurance even though their income depends on the whims of nature. It is essential that insurance in Serbia takes place which insurance has in modern, developed economies. This can be encouraged both by state and credit institutions that help the development of agriculture, from insurers, but also by the farmers themselves (Mahul, Stutley, 2010). 
Proposals can occasionally be heard in Serbia on the introduction of compulsory insurance of agricultural production by adopting appropriate legislation. One of the alternatives is the issue of voluntary or compulsory insurance of agricultural production. We pointed out that in most countries this insurance voluntarily (Diaz-Caneja et al., 2009).

Given that we are in a country with a large number of taxes, duties and other government levies, we believe that this wouldn't yield results in increasing premiums, because in this type of insurance relations can't be built on force, but on the economic interests of all stakeholders. All farmers would consider obligatory insurance of fruits and crops as additional costs. The economy as a system is under great pressure of securing budget revenues, businessmen in Serbia are constantly stating their displeasure with tax obligations they have and the fact that there are far fewer employees in the economy in relation to the public sector.

Seeing as how the insurance of agricultural production is seasonal work, many producers insure their crops during the spring works. The insurer often concludes a contract with executing an overview of the object of insurance because of the volume of work, with which he is making a big mistake. It's his duty is to determine the condition of crops in the field, in the first place whether the crop are there, and then to assess whether the yield that insured aims to is expected and realistic for the area (Žarković et al., 2014).

The performance of insurance companies that deal with risk coverage of fruits and crops is not of continuous character. They often give deals with huge discounts, with which they are brought into a situation where they can't provide the adequacy of funds to cover the assumed risk. With this they provide market share for themselves but unfairly (Vukoje, 2013).

As we have seen in the analysis of results displayed, damage is not directly commensurate with regard to arable land, and in order for the insurance mechanism to function it is necessary to respect tariffs, objectively show results and the state should divert more attention to control and supervise these insurance companies. Regardless of the poor results, a relatively small premium, it is essential that farmers gain confidence and that is possible only in conditions of fair market, whose guarantor is the state legal system.

Great importance and encouragement to the development of insurance business, to a larger number of contracts and raising awareness of farmers was given by the state by introducing subsidies. Although in 2012 only 14,871 insurance policies were contracted, refund of premiums in a certain percentage as a subsidy provided by the state, gave the results in terms of increasing the number of contracts, secured arable land and insurance premiums.

Due to lack of information, low awareness of the importance of insurance protection and ignorance on the conditions of insurance of fruits and crops, farmers view insurance as a cost they can do without. This is especially noticeable in years in which there was no damage. The concentration of insured areas is for the most part in hail areas. Therefore a continuous access for the insurer to education of farmers is necessary, as well as offering insurance protection not only during the season of agricultural work. Insurers have to work much more on familiarizing farmers with the benefits provided by insurance production. 
One of the more specific risks in the insurance of agriculture is drought. In Serbia, only one insurance house covers that risk, along with quite a complex process of claims processing. Assessment of the damage done by an appraiser based on meteorological data but he can take into account the shortcomings of the technological process, with which damage can be greatly decreased or even repelled. Drought is a phenomenon which covers a wide area, typically the entire country and could lead to a significant drop in the yield of agricultural crops, thus significantly affecting the overall food production (Dragović, 2001).

The role of prevention is to reduce the probability of risk or to forestall the occurrence of adverse events on insured crops and fruits. Directions of preventive action depends in the first place from the dangers that threaten crop production. Prevention should focus on the causes of the damage which are dominant. Seeing as how hail brings the most damage, the most effective protection against hail is an anti-hail net which is too expensive for many manufacturers. Antifreeze systems are also beneficial. This provides, next to the protection against frost, harvest of fruit when it rains and crops are protected against hail. Preventive measures should be far more those that are included in agricultural risk management in our country (AXCO, 2014).

By expanding insurance coverage to arable land in less risky areas, greater dispersion of risks and a better technical result would be achieved. From the analysis it can be seen that by the increase in arable land there was higher insured area with previously mentioned increase of comprehensiveness of arable land insurance coverage which would achieve enviable results.

An increase in the total utilized agricultural area would probably in the same percentage increase arable land. If other conditions for better functioning of the insurance business were met such as raising awareness of farmers on such form of protection, by government measures in terms of stimulating agricultural production and relative share in the premium paid by the farmer, raising the level of activity of insurers to offer products and improved accuracy in rehabilitation etc. would probably make the percentage of the insured area grow faster. Estimates of growth in insurance business from the beginning of this century were in hundreds, which also applies to insurance of agriculture. We still have that potential in ensuring agricultural production, but it should be up and coming.

With greater diversification and atomization of risk, with large amounts of insurance premiums would grow faster than the damage. Of course, one should bear in mind the element of surprise but it certainly exists. In the reporting period, the technical result is positive on average. In the last year of the observed period, 2013 even though it had worse outcome it is not authoritative to confirm the thesis because it is normal for such a long period to have years with bad results and years that carry greater risks. However, it is applicable to the insured by increasing the surface area increases with higher premiums and premiums have a better result.

\section{Literature}

1. AXCO (2014): Insurance Market Report Serbia: Non-Life (P\&C), AXCO, London, Great Britain.

2. Brkanić, M. (1996): Priručnik za praksu u osiguranju i reosiguranju, DDOR Novi Sad, Novi Sad, Serbia. 
3. Carter, C., Smith, A. (2007): Estimating the market effect of a food scare: The case of genetically modified starlink corn, The Review of Economics and Statistics, vol. 89, no. 3, pp. 522-533, MIT Press Journals, Cambridge, MA, USA.

4. Chambers, R.G., Quiggin, J. (2004): Technological and financial approaches to risk management in agriculture: an integrated approach, Australian Journal of Agriculture and Resource Economics, vol. 48, no. 2, pp. 199-223, Wiley/Blackwell, Milton, Queensland, Australia.

5. Costello, R.M. (2012): Crop insurance: Iowa license exam manual, CreateSpace, Seattle, WA, USA.

6. Diaz-Caneja, B., Conte, M., Giulia, C., Pinilla, G., Javier, F. (2009): Risk management and agricultural insurance schemes in Europe, European Commission, The Institute for the Protection of the Citizen, Ispra, Italy.

7. Dragović, S. (2001): Potrebe i efekti navodnjavanja na povećanje i stabilizaciju prinosa u poljoprivrednim područjima Srbije, Zbornik radova Instituta za ratarstvo i povrtarstvo, vol. 35, pp. 445-456, Institut za ratarstvo i povrtarstvo, Novi Sad, Serbia.

8. Mahul, O., Stutley, C.J.(2010): Government support to agricultural insurance: challenges and option for developing countries, World Bank Publications, Washington DC, USA.

9. Maliva, R.G., Missimer, Th.M. (2012): Air Lands Water Evaluation and Management, New York, Springer, USA.

10. Marković, T., Jovanović, M. (2008): Postojeći sistemi osiguranja useva i plodova kao instrument za upravljanje rizikom u poljoprivredi, Agroekonomika, vol. 39-40, pp. 104110, Departman za ekonomiku poljoprivrede i sociologiju sela Poljoprivrednog fakulteta u Novom Sadu, Novi Sad, Serbia.

11. Morgan, W., Cotter, J., Dowd, K. (2012): Extreme measures of agricultural financial risk, Journal of Agricultural Economics, vol. 63, no. 1, pp. 65-82, Wiley, Hoboken, NJ, USA.

12. National Bank of Serbia, Insurance Sector in Serbia - Third Quarter Report, (available at: http://www.nbs.rs/export/sites/default/internet/english/60/60 6/insurance _II 2014.pdf).

13. Roberts, R. A. J. (2005): Insurance of crops in developing countries, Food and Agriculture Organization of the United Nations, Rome, Italy.

14. Statistical Office of the Republic of Serbia (2012): Statistical Yearbook of the Republic of Serbia, Statistical Office of the Republic of Serbia, Belgrade, Serbia.

15. Swiss Re (2011): Product innovation in non-life insurance markets, Sigma, No. 4, pp. 1-36, Swiss Re, Zurich, Switzerland.

16. Swiss Re (2011a): Insurance in emerging markets: growth drivers and profitability, Sigma, No. 5, pp. 1-35, Swiss Re, Zurich, Switzerland.

17. Tsakiris, G., Vangelis, H. (2005): Establishing a Drought Index Incorporating Evapotranspiration, European Water, 9/10, pp. 3-11, E. W. Publications, Athens, Greece. 
18. Vukoje, A. (2013): Faktori egzistencije kao uslov stvaranja tržišne pozicije preduzeća, Oditor, no. 5, pp. 27-37, CEFIS, Beograd, Srbija.

19. Wright B. D., Hewitt J. A. (1994): All-risk crop insurance: lessons from theory and experience. In: Hueth D.L. and Furtan W.H. (Editors), Economics of agricultural crop insurance: theory and evidence, Springer, New York, USA.

20. Republički geodetski zavod, Popis poljoprivrede, 2012. (available at: www.rgz.gov.rs).

21. Žarković, N., Toscano, B., Mrksic, D., Lisov M. (2014): Key features of crop insurance in Serbia, Bulgarian Journal of Agricultural Science, Vol. 20, No. 1, 23-33, Agricultural Academy, Sophia, Bulgaria.

22. http://www.nbs.rs/export/sites/default/internet/english/60/60 2/izvestaji/god T1T2 2012.pdf.

\title{
MOGUĆNOSTI POLJOPRIVREDNE PROIZVODNJE I NJIHOV UTICAJ NA PREMIJU OSIGURANJA
}

\author{
Jelena Birovljev ${ }^{4}$, Željko Vojinovićc ${ }^{,}$Mladenka Balaban ${ }^{6}$
}

\begin{abstract}
Sažetak
Proizvodnja hrane u svetu postaje izuzetno važna i zadobija značaj u poređenju $s$ drugim aktivnostima. Kako broj stanovnika na planeti raste, proizvodnja hrane sve će više zadobijati na značaju. Na nju će u ubudućnosti zacelo uticati klimatske promene, a to će biti praćeno i promenama u osiguravajućem pokriću. Za zemlje u razvoju je osobeno što se obradivo zemljište ne koristi na pravi način $i$ što je osiguravajuća zaštita za useve takođe nerazvijena. Za Srbiju, koja pripada skupini zemalja u kojima se ostvaruju niski prinosi poljoprivrednih useva, možemo istaći da se osiguranjem ne pokriva zadovoljavajući deo obradivih površina. Razlog za to leži u nepoverenju mogucih osiguranika, niskoj svetsti o osiguranju kod stanovnika, privrednoj politici koja se sprovoti po tom pitanju, neodgovarajućoj obuci zastupnika osiguranja $i$ nedostastku primerenih osiguravajućih usluga.
\end{abstract}

Ključne reči: poljoprivredna proizvodnja, siguranje biljne proizvodnje, premija osiguranja, osiguravajuća društva, osiguranje u Srbiji.

4 Redovni profesor, dr Jelena Birovljev, Ekonomski fakultet u Subotici, Univerzitet u Novom Sadu, Segedinski put 9-11, Subotica, Srbija, Phone: +381 6383959 71, E-mail: birovljevj@ef.uns.ac.rs

5 Vanredni profesor, dr Željko Vojinović, Ekonomski fakultet, Nezavisni Univerzitet, Banja Luka, Veljka Mladenovića 263- 12 E, BiH, Telefon: + 381648832600 E-mail: zv@,inbajmok.com

6 Vanredni profesor, dr Mladenka Balaban, Institut Ekonomskih Nauka, Beograd, Zmaj Jovina 12, Beograd, E-mail: mladenka.balaban@ien.bg.ac.rs 